\title{
VISIONS OF POWER AND DISPOSSESSION: EMERSON, WHITMAN, AND THE "ROBUST SOUL"
}

\author{
John Michael Corrigan
}

IN "SONG OF MYSELF," Walt Whitman portrays his own poetic evolution with the image of a stairway. Standing on the top rung of a flight of steps, the poet has earned, after "trillions of winters and summers," a new power to "launch all men and women forward with [him] into the Unknown."1 In mounting the staircase and assimilating all the knowledge that each step or age provides, Whitman declares his emergent power to be the culmination of the soul's experience of a vast temporal sequence: "All forces have been steadily employ'd to complete and delight me, / Now on this spot I stand with my robust soul" ( $L G, 81)$. This article explores Whitman's conception of the "robust soul" in "Song of Myself" and the 1855 Preface to Leaves of Grass by locating it in a larger mystical tradition and emphasizing an unnoticed feature of Emerson's influence on Whitman. Emerson's adaptation of the Platonic ladder of ascent and his metempsychotic self of "History" inform Whitman's evocation of how the soul educates itself by climbing the ladder of being in an attempt to reach the end of the sequence and to attain the power of creation. Whereas the ancients described the journey of the soul through the natural world over the course of lives and ages, Emerson insisted on understanding the soul's ascent as a metaphor for individual power, a process by which the materials of history could be assimilated by a single, evolving consciousness. Whitman, in turn, integrates Emerson's conception of ascent into the very structure of his poetics, so that the evolution and expansion of the human self unfolds as a relationship between the reader and the printed page.

Whitman's depiction of the highly charged process of ascending poetic maturation also reflects a growing uneasiness with the transcendentalist notion of power. Certainly, Whitman espouses the vast arena of the American self: "I am an acme of things accomplish'd, and I an encloser of things to be" $(L G, 80)$. But often present are the perspectives of the dispossessed, those who will not enjoy the ideal democratic pact to come and are subsumed as raw materials for the ascent into this new America. Whitman's unsettled poetics of self thereby underscores 
a crisis, a yearning for transcendental power alongside a self-critical stance that forces his audience to experience defeat and weakness. The ability for self-expansion, Whitman shows, must include a growing awareness not just of the power of the whole, but of what is sacrificed for such unity.

In Upheavals of Thought (2001), Martha Nussbaum argues against modern rationalist paradigms and asserts instead that emotions shape our mental and social lives, operating as implicit value-judgments with their own non-rational, but cognitive structures. She applies this theory to several quasi-Platonic "ladders of ascent" in the history of thought by examining the tension between the energy of the love for the good and the subversive power of such energy. These "ladders of ascent" (ultimately dependent upon Plato's Symposium) are as follows: first, one that focuses upon contemplation of the Good and the Beautiful (Plato, Spinoza, Proust); second, a Christian version of ascent that stresses humility, longing, and grace (Augustine, Aquinas, Dante); third, a Romantic version that rejects a telos for ascent (Emily Bronte, Mahler); and finally, a "descent of love" in which human desire sets itself the task of embracing the imperfect with love (Whitman and Joyce). In the case of Whitman, Nussbaum argues that his "descent of love" proposes a new "counter-cosmology" to those "created by philosophical and religious systems." 2 Whitman's focus on the body and his rehabilitation of sex in "Song of Myself" "with its daringly erotic depiction of the relationship between the poet and his God, and between his body and his soul" result, in Nussbaum's judgment, in a "cosmology of our finitude and imperfection," a materially adapting process where there is no transcendence, in any traditional sense $(658,661)$. Instead, there "is just life, renewing itself; and the only continuity for the human being is the continuity of nature and of human civilization" (658).

Nussbaum is much more adamant than other critics that Whitman replaces "Plato's world of transcendental forms" with a vision in which the only transcendence that makes sense "is the transcendence of partiality and faction in sympathy, of hierarchy in equal respect, of oppression in citizenship and voting, of hatred in love" (658). While her reading captures the major themes of bodily affirmation alongside the rejection of feudal hierarchy, Nussbaum overlooks the extent to which Whitman engages in an American reinterpretation of the mystical tradition of ascent in terms of selfhood. Emerson's figurative depiction of the self as the "metempsychosis of nature" in "History" (1841) provides an instructive prototype for the kind of expansive self Whitman poeticizes in "Song of Myself." 3 Emerson's assimilation of Hindu reincarnation and Pythagorean and Platonic metempsychosis into a new, subjective model for selfhood can be understood in conjunction with the Romantic Idealist desire to unify emerging scientific knowledge with traditional 
metaphysics. "Man is explicable by nothing less than all his history," Emerson writes, arguing that "the entire series of days" provides an expansive chronology that an individual must seek to embody in his or her own person $(C W, 2: 3)$. Emerson at once cautions his readers that "the transmigration of souls is no fable" and instructs them that in order to know themselves they must rediscover the whole ground of history in themselves: "Every mind must know the whole lesson for itself,-must go over the whole ground. What it does not see, what it does not live, it will not know" ( $C W, 2: 18,6)$. The "metempsychosis of nature"-the journey of the soul into successive bodies-becomes a mystical trope for the work of human consciousness to remember the whole ground of history in itself and, thereby, to take on as many perspectives as possible in a titanic effort to reshape the fragmentary self into a complete entity.

In "History," therefore, a dynamic and uneasy reassessment of metaphysics and science takes place. Emerson modifies the esoteric view that nature is a symbolic language for the spiritual world to include the vastness of the geological record and theories of biological adaption that were emerging in the sciences. No longer does spirit simply create the body in a straightforward doctrine of correspondences; rather, the individual's "power consists in the multitude of his affinities, in the fact that his life is intertwined with the whole chain of organic and inorganic being" ( $C W, 2: 20)$. As Emerson wrote almost a decade earlier in an 1833 lecture on science, the human being only "seems" to be "made perfect in the image of the Maker"; he is, more properly, an adaptation of all that has preceded him: "but his limbs are only a more exquisite organization, - say rather - the finish of the rudimental forms that have been already sweeping the sea and creeping in the mud; the brother of his hand is even now cleaving the Arctic Sea in the fin of the whale, and, innumerable ages since, was pawing the marsh in the flipper of the saurus." "While incorporating such emerging scientific knowledge into his essays, Emerson does not discard the mystical tradition he so admired; rather, he attempts an admixture of the two views to form a new spiritual science. In "History," he directly portrays the transmigration of souls in terms of spiritual evolution or devolution, for human beings are not the ideal creation, but rather suggestions of a higher possibility in nature:

The transmigration of souls is no fable. I would it were; but men and women are only half human. Every animal of the barn-yard, the field and the forest, of the earth and of the waters that are under the earth, has contrived to get a footing and to leave the print of its features and form in some one or other of these upright, heaven-facing speakers. Ah! brother, stop the ebb of thy soul-ebbing downward into the forms into whose habits thou hast now for many years slid. (CW, 2:18) 
Emerson explicitly imagines the metempsychotic development of the self in terms of ascent and, conversely, descent. Human beings are only half-human, he declares; and they must participate more directly in their evolution if they are not to de-evolve in the scale of nature by "ebbing downward" into lower forms. To "go over the whole ground" of history thereby becomes the principal task of cognition-and Emerson repeatedly depicts this task with the imagery of the steps of a stairway or ladder: "we aim to master intellectually the steps, and reach the same height or the same degradation that our fellow, our proxy has done" $(C W, 2: 6,7)$.

As the leading piece of Essays: First Series, Emerson's “History" sets a precedent for the essays that succeed it. "Love" (1841) recapitulates the mind's journey through "the entire series of days," interweaving the idea of the material, historical series with mystical ascent. "As life wears on," Emerson writes of the lover and beloved, "it proves a game of permutation and combination of all possible positions of the parties, to employ all the resources of each, and acquaint each with the strength and weakness of the other" (CW,2:108). To experience the whole, Emerson argues, one must actively attempt to experience every possible variation in nature. Here, the lover's growing experience of "all possible positions" in relation to the beloved suggests the influence of the early probability theory of Pierre-Simon Laplace (1749-1827) and its sociological adaption by Adolphe Quetelet (1796-1874). Truth is not a matter of one possibility, but rather the sum total of every perspective, even those trajectories which prove incorrect. ${ }^{5}$ In characteristic fashion, Emerson is sure to set this deterministic view within the context of mystical ascent: "the lover ascends to the highest beauty, to the love and knowledge of the Divinity, by steps on this ladder of created souls" (CW, 2:106).

In "Circles" (1841) as well, Emerson celebrates individual power as a process that consists of climbing the ladder of ascent to reach the end of the sequence: "Step by step we scale this mysterious ladder: the steps are actions; the new prospect is power" $(C W, 2: 181)$. In scaling the ladder, the individual will eventually come to the final step of the historical series with the soul's power to realize a higher reality in nature: "There are no fixtures to men, if we appeal to consciousness. Every man supposes himself not to be fully understood; and if there is any truth in him, if he rests at last on the divine soul, I see not how it can be otherwise. The last chamber, the last closet, he must feel, was never opened; there is always a residuum unknown, unanalyzable. That is, every man believes that he has a greater possibility" ( $C W, 2: 182)$. Where, in "History" and "Love," Emerson depicts an individual's ability to unite cognitively every step of the ladder as an initial poetic task, 
in "Circles," he emphasizes how poetic creation ultimately takes place at the end of the series. No longer determined by a pre-established sequence, the individual comes "to rest at last on the divine soul." In short, he or she has gained the power of the soul to realize "a greater possibility" in nature and to extend the series outward into a more perfect inscription. After it has run through, and understood, the series of which it is a part, "the fine touch of [the poet's] eye . . . deigns to draw a truer line" (CW, 6:163).

While Emerson often champions the ability of the human being to assimilate the historical series in a heightened act of becoming, he just as often problematizes the prospect of ascent as an impossible cognitive feat. The opening of "Experience" (1844) evokes a dilemma of consciousness that demonstrates Emerson's skepticism and expresses his underlying mystical sensibility. Directly addressing his readers, Emerson invokes the metempsychotic self of "History" by declaring that we, like the souls in Plato's Myth of Er in the last book of The Republic, have been purged of all our knowledge of past lives by Lethe's waters. Consequently, we glide ghostlike through nature in search of self-knowledge so as to answer a most basic question:

Where do we find ourselves? In a series, of which we don't know the extremes, and believe that it has none. We wake and find ourselves on a stair: there are stairs below us, which we seem to have ascended; there are stairs above us, many a one, which go upward and out of sight. But the Genius which, according to the old belief, stands at the door by which we enter, and gives us the lethe to drink, that we may tell no tales, mixed the cup too strongly, and we cannot shake off the lethargy now at noonday. . . . Ghostlike we glide through nature, and should not know our place again. $(C W, 3: 27)$

Like the transmigrating individual of "History" who is only half-human, the self in "Experience" wakens to find himself midway on an apparently never-ending stairway of ascent. Although he cannot remember how he arrived in this present place on the stair that rises upward beyond his perceptual range, he must attempt to recollect the greater arc of the ontological series so as to "know [his] place again." What is at stake in such a spiritual odyssey is no less than the discovery of America itself: "I am ready to die out of nature and be born again into this new yet unapproachable America" ( $C W, 3: 41) .{ }^{6}$ Like the essay's opening, however, Emerson is sure to present this prospect of individual and national transmigration alongside the sure limitations of human experience. The individual's immense effort to know his or her place again-and so discover the possibility of a new constitution for being-becomes simply "the solitary performance" of a "puss" chasing "her tail," a subject/object relationship that continues indefinitely $(C W, 3: 46)$. The 
metempsychotic stairway of "Experience" thereby presents both a dilemma of consciousness and an opportunity for self-recovery: "We must hold hard to this poverty, however scandalous, and by more vigorous self-recoveries, after the sallies of action, possess our axis more firmly" $(C W, 3: 46)$. Here again, Emerson evokes the upward metempsychotic journey of consciousness as a central prototype for individuality. While the human being is initially inscribed within the series, located on just one step of being, he may yet reconstitute himself anew by using his immanent power to guide him upward on the stair toward fresh worlds: "in the solitude to which every man is always returning, he has a sanity and revelations, which in his passage into new worlds he will carry with him. Never mind the ridicule, never mind the defeat: up again, old heart!" $(C W, 3: 49){ }^{7}$

In "Song of Myself," Whitman poeticizes the metempsychotic self of Emerson's essays. Indeed, to "see and hear the whole," the poet must "take part" in the larger, human struggle, which means becoming the "hounded slave," the "mash'd fireman with breast-bone broken," and the "old artillerist" who has to witness the death of his general before being able to inhabit the "next fold of the future" ( $L G, 67,66,67,88)$. Like Emerson, Whitman does not portray the movement into other selves traditionally - as in both the Hindu and Neoplatonic traditions, where the soul endures multiple lives and attempts to transcend matter. Rather, he conceives of "the interiorizing of objects as an ingestion, a magical incorporation of the world into the body." "I fly those flights of a fluid and swallowing soul," Whitman writes in Section 33 of "Song of Myself" $(L G, 65)$, repeating the idea with the force of a poetic declaration some lines later: "All this I swallow, it tastes good, I like it well, it becomes mine, / I am the man, I suffer'd, I was there" ( $L G, 66)$. These lines are more than a casual boast. As Philip Fisher argues, "behind Whitman's words . . . lies the staggering fact that [they] are spoken not about a proud moment of his own experience, but out of his claim to be able to be someone else." 9

Donald E. Pease was one of the first scholars to examine Whitman's belief that he could inhabit all conceivable American identities. For Pease, Whitman's supposition that "everything is itself and is on the way to becoming all" is based upon "eradicat[ing] the distinction between the reflections within the mind and things in the world." "Individuals," in Whitman's poetry, "do not reflect upon things but project them into what they can be, thereby extending what we more usually call memory, or the work of reflection, into the future." ${ }^{\prime 10}$ This "most elusive aspect of Whitman's poetry," Pease argues, consists essentially in "identifying the self with the evolutionary process, rather than any single individual" (149). Whitman's claim to be someone else 
infuses his epic with a strange combination of mysticism, evolution, and democratic practice, but it is most substantially a claim that directly aligns him with Emerson. While a number of critics have noted that "Whitman's belief in reincarnation . . . provided the poet with a structure for his oceanic views concerning selfhood," 11 no one has observed that Emerson's characterization of the cognitive expansion and accompanying biological adaptation of the individual self as an ever-ascending metempsychotic series provides a decisive prototype for the kind of reincarnation Whitman has in mind. ${ }^{12}$

Harold Bloom argues that Emerson's doctrine of power "resides in the moment of transition from a past to a new state, in the shooting of a gulf, in the darting to an aim" (CW, 2:40) —and what is just as "urgent for Walt is the crossing, Emerson's metaphor for darting to a new aim."13 Such power consists not simply in the transition to a new aim or the transcendence of one self for another, but in the simultaneous integration of what is abandoned in a new vista of heightened being. For Emerson, as we saw, exceeding the series means gaining the power of the soul to unify and extend history's series - and, in "Song of Myself," Whitman explicitly promises such power to his readers. They too may learn to escape history's mimetic inscriptions and possess an individual power in which everything external has been fully integrated into being:

Stop this day and night with me and you shall possess the origin of all poems, You shall possess the good of the earth and sun, (there are millions of suns left,)

You shall no longer take things at second or third hand, nor look through the eyes of the dead, nor feed on the spectres in books,

You shall not look through my eyes either, nor take things from me,

You shall listen to all sides and filter them from your self. ( $L G, 30$; emphasis added)

To attain the origin of all poems, the reader must first overcome the mimetic mediation - the "second or third hand"-that so obscures his vision. While Whitman promises this freedom from mimesis to his readers and, by implication, to himself, he also tacitly suggests an unavoidable conflict. The individual may learn to "listen to all sides" of creation and "filter them" through himself, but his attempts-in his present position - take place in the wake of creation, not at the forefront of it. Although his perceptive powers may promise a new vista for experience, such power is nonetheless deferred. As a result, the reader currently peers through the eyes of the dead-through the mimetic weight of creation - toward an elusive freedom and unity that can be his only if he learns to ascend the series and initiate creation's incessant push outward.

Whitman's poet thereby provides a spiritual example to the greater American public. In assuming identities and mounting the steps of an 
ontological stairway, the poet gradually gains the power of creation itself, achieved not simply in ascension, but in a spiritual culmination at the top rung of the stair of being. In Section 44 particularly, Whitman uses the image of an ascending stairway to illustrate the evolutionary aspiration of the self through time: "My feet strike an apex of the apices of the stairs, / On every step bunches of ages, and larger bunches between the steps, / All below duly travel'd, and still I mount and mount" $(L G, 81)$. Combining the idea of the vast historical series of being with the mystical stairway of ascent, Whitman portrays the movement of the speaker through "bunches of ages" or multiple selves as a poetic process culminating in new power. The emphasis upon the image of "feet," metrical measurements in poetry, suggests the act of reading is a form of ascension, which eventually arrives at, or "strikes," an "apex," a point of spiritual culmination, which provides coherence and meaning in the emergent, presently unfolding scheme of individual and collective development: "All forces have been steadily employ'd to complete and delight me, / Now on this spot I stand with my robust soul" ( $L G$, 81). Here, Whitman recasts the soul's experience of the entire series of days as an expressly poetic venture. Where Emerson often conceived of the soul's experience of the stairway of being as a phenomenological inquiry, Whitman imagines the soul's relation to the series much more precisely as a structural component of his own poetry. It is not simply "the long slow strata" of ascending geological formations or the "monstrous sauroids" that transport the soul from one height to another, but also the metric sequence itself which serves as the physical template upon which the poet ascends in a spiritual strengthening that takes place at the top of the stairway of being $(L G, 81)$.

While Whitman announces himself as the poet of both the soul and the body, the soul nonetheless possesses a particular distinction in "Song of Myself." Whitman repeatedly imagines ascension as the arduous quest of metempsychotic integration in order to attain an unmediated relationship with the soul. In Section 25, it is precisely this art of ascension that wards off the physiological limitations of the human body and allows the poet to access the eternal energy of the soul. In order to overcome the killing rays of the sun, the poet must do more than assume bodies; he must propel himself upward toward renewal: "We also ascend dazzling and tremendous as the sun, / We found our own O my soul in the calm and cool of the daybreak" (LG, 54). Harold Bloom calls this "movement from I, the persona Walt Whitman, to We, self and soul together" a "triumph" of the American sublime, a transcendence of the traditional "limitation of finding [one's] own soul unknowable." 14 From a more precise vantage point, Whitman instills the mystical delineations of ascent into his poetry, especially 
Emerson's conviction that the soul's power is finally made manifest at the end of the historical series of being. In "Song of Myself," therefore, the poet climbs history's pre-established sequence, finding at long last an express mutuality with his soul, which ever-compels the poet "to continue beyond":

This day before dawn I ascended a hill and look'd at the crowded heaven, And I said to my spirit When we become the enfolders of those orbs, and the pleasure and knowledge of every thing in them, shall we be fill'd and satisfied then?

And my spirit said No, we but level that lift to pass and continue beyond. (LG, 83-84)

Here, Whitman integrates the ascension of Section 25 and the robust soul of Section 44 into a conversation between self and soul, the poet asking if his metempsychotic assimilation has been completed and the soul answering that the movement upward must continue perpetually. The poet has thereby learned to converse directly with his soul by virtue of ascending the historical series of being. At every plateau, he assimilates the materiality he sees and attains the long-promised "origin all poems." It is not a process achieved in spiritual isolation. Whitman evokes the process in direct relation to his readers, who will attempt to mount the series for themselves so as to assume what the poet assumes, as the second line of the poem indicates.

In the 1855 preface to Leaves of Grass, Whitman has already prepared his readers to imagine this kind of relationship between reader and writer in terms of ascent. Indeed, the movement upward toward robust power is not an occasional metaphor; it constitutes Whitman's poetic challenge to his audience. "If [the poet] does not flood himself with the immediate age as with vast oceanic tides" and does not make "the present spot the passage from what was to what shall be [...]let him merge in the general run and wait his development." ${ }^{15}$ Here, "the present spot" anticipates the stairway of being in "Song of Myself," for the privileged place between past and future that Whitman announces in the preface expressly prefigures "this spot" on which "I stand with my robust soul." Whitman thus gives two choices to his audience- the first being a deferral of poetic maturation and the other, a metempsychotic integration of history into the self, a process in which the spiritual aspires upward through history's vast sequence until it transforms these materials into the promise of the present moment: the "eternity [ . . . ] rises up from its inconceivable vagueness and infiniteness in the swimming shape of today" ( $L G 1855, \mathrm{xi}$ ). Whitman thereby invites his readers to watch the "greatest poet" ascend the ladder or stairway of being so as to climb through the textual series and disappear beyond the last word. In witnessing the spectacle, the reader is compelled either to follow the poet or to remain behind among all the cultural forms over which he 
still has no power: "The greatest poet does not only dazzle his rays over character and scenes and passions . . . he finally ascends and finishes all . . . he exhibits the pinnacles that no man can tell what they are for or what is beyond . . he glows a moment on the extremest verge. $\mathrm{He}$ is wonderful in his last half-hidden smile or frown . . . by that flash of the moment of parting the one that sees it shall be encouraged or terrified afterward for many years" ( $L G$ 1855, vi; emphasis added). To gain the power of the poet, "to glow on the extremest verge," is, to a large extent, the central preoccupation of the 1855 edition of Leaves of Grass - and Whitman equates this endeavor with the experience of ascent, a sublime, evolutionary process from or to which the reader either shrinks or turns.

Whitman's depiction of the poet's disappearance or "moment of parting" that leaves the reader "encouraged or terrified" can also be understood as a direct response to Emerson's articulation of the future poet as "an object of awe and terror." In Emerson's "The Poet" (1844), the reader must consider if he appears "a man to all eyes" or whether the poet - who has a fuller experience of the stairway or ladder of ascent and, thus, has undergone a greater development or evolution on it-perceives the reader from another, higher evolutionary vantage point $(C W, 3: 21)$. In the 1855 preface, Whitman intensifies this relationship between reader and poet by imagining his own poetic form as an ascending series on which two prospective identities play: the reader ascending through the textual sequence and the poet hovering just above or beyond the series. Once the reader has witnessed the poet on "the extremest verge" of the ascending poetic series transcending the last word, the reader musters the courage to attempt such transcendence, but he does not achieve this feat alone; he is aided by the poet who now "takes" the reader with "firm sure grasp" into "living regions previously unattained":

The touch of him tells in action. Whom he takes he takes with firm sure grasp into live regions previously unattained . . . thenceforward is no rest . . . they see the space and ineffable sheen that turn the old spots and lights into dead vacuums. The companion of him beholds the birth and progress of stars and learns one of the meanings. Now there shall be a man cohered out of tumult and chaos . . . the elder encourages the younger and shows him how . . . they two shall launch off fearlessly together till the new world fits an orbit for itself and looks unabashed on the lesser orbits of the stars and sweeps through the ceaseless rings and shall never be quiet again. ( $L G 1855$, xi)

In a very specific manner, Whitman adapts traditional transcendence and makes it applicable to the reading and writing process; he presents it as a form of physical love and intimacy whose upward and downward gravities find an express mutuality and union: the elder descends into 
the series so as to take hold of the younger and help him ascend toward new creation, so that they can "see the space and ineffable sheen" of new life. The elder's instruction allows the younger to "behold [for himself] the birth and progress of stars," and this pedagogical, poetic and erotic project is transformed from one which initially contains an implicit power structure - the elder grasping the younger and leading him upward - to one of emergent equality. Once the "elder encourages the younger and shows him how" to perceive the prospect of new creation, the two of them "launch off fearlessly together" to engender this "new world." Fittingly, Whitman's pronouncement of future unity"Now there shall be a man cohered out of tumult and chaos"-possesses a necessary ambiguity. The exact identity of this prospective man remains unclear; he is neither the elder nor the younger, but both together; their partnership has allowed a new entity to cohere out of division and chaos. What was, on one level, a pedagogical lesson in reading poetry has led to the emergence of a new individual unity or "robust soul," which repeats the universe's push outward on an even higher and more fortified ontological level.

What began then as a simple reading process soon becomes a tangible "touch" between reader and poet, a process which both transcends and simultaneously affirms the very physicality of "the new world." Perception prepares for creation, since the companions' journey into this new region entails the organ of sight, but the emphasis on the "firm sure grasp" of actual, physical friendship or homoerotic love along this journey is Whitman's own, a decidedly human touch that binds and coheres what was always prospective or even impossible in Emerson. Certainly, the delineations of Emerson's metempsychotic self inform the way that Whitman presents the end of the stairway as the spot on which two energies, one coming from below and the other from above, coalesce "to launch off fearlessly [ . . . ] till the new world fits an orbit for itself." But Whitman much more fully imagines such a spiritual reshaping of the self as a decisive part of the reading process, which offers the most intimate of experiences, the ecstatic bond between master and apprentice, reader and poet, lover and beloved, a process much more reminiscent of the actual stages of Platonic ascent. In Plato's Symposium, for instance, Diotima's pupil does not just see the Good or the Beautiful; the disciple's ascent is an arduous path where persistent and wideranging study eventually leads the student to become a master-creator in his own right: perception gives way to touch, a perceptual physicality which may be either lost or emphasized according to the dialogue's translator. In Percy Shelley's translation of the Symposium, one of the translations most readily available to Whitman, the movement toward creation is explicit and does not evoke a conventional or stereotypical 
Platonism where soul simply throws off the body. Rather, Diotima assures Socrates that "earnest Love is a tendency towards eternity" and that the pregnancy of the body can lead to an even more potent pregnancy of the soul; subsequently, the pupil is told not to enslave himself to one or another form if he "would turn towards the wide ocean of intellectual beauty, and from the sight of the lovely and majestic forms which it contains, would abundantly bring forth his conceptions." 16 Shelley captures the physicality that is a decisive part of this process, since the ascent employs sexual images in describing the eventual pregnancy of the soul wishing to procreate upon the beautiful, which comes in its highest manifestation to entail touch: "When any one, ascending from a correct system of Love, begins to contemplate this supreme beauty, he already touches the consummation of his labour" (57).

Contrary to Nussbaum's insistence upon the "descent of love," Whitman's 1855 preface and "Song of Myself" emphatically depict the empowerment and expansion of the self in terms of the robust soul, an ascending spiritual fortification, which possesses a further Emersonian and Idealist angle of interpretation. In an 1842 journal, Emerson conceives of the robust soul in terms of dialectic, a simultaneous movement downward to material singularity and upward to unified multiplicity: "A spark of fire is infinitely deep, but a mass of fire reaching from earth upward into heaven, this is the sign of the robust, united, burning, radiant soul." In "Love" (1841), Emerson interprets this fiery dialectic in relation to the ladder of ascent from Plato's Symposium, showing how the ladder becomes the locus upon which opposing gravities play: a "celestial rapture falling out of heaven" takes root in the "private heart" of one individual and soon passes its "spark" to others "until it warms and beams upon multitudes of men and women, upon the universal heart of all, and so lights up the whole world and all nature with its generous flames" ( $C W, 2: 100)$. For Emerson, the soul's circular movement downward out of heaven and upward in a mass of fire is not a one-time activity, but constituted and informed by multiple journeys up and down the ladder of being, its re-ascent characterized by the fact that it has already descended into matter. His conception of the soul's descent and ascent toward robustness, in fact, echoes a well-established Neoplatonic tradition in England. In the commentary to the famous eighteenth-century translation of Plato's Symposium, The Banquet: A Dialogue of Plato Concerning Love (1767), Floyer Sydenham argues that the Platonic ladder involves both descent and ascent. The soul in moving up the rungs towards the Sovereign Beauty remembers that it has inhabited these steps before, albeit under an opposing gravity, and is not liable to destruction since its present movement upward rejuvenates it and asserts its inward power against decay. ${ }^{18}$ Nussbaum captures de- 
cisively "the descent of love" towards an affirmation of the finite body, a "counter cosmology" in which Whitman "affirms the Aristotelian view that the body is the soul" (660). But Whitman portrays a more complex soul/body relationship that emphasizes how the soul takes on the body and lives through its sequence until it comes to the end of that sequence fully fortified and strengthened to enact the process yet again.

Whitman's implicit adaptation of Emerson's robust soul therefore captures the Platonic notion of ascent in the Symposium, particularly Diotima's final step on the ladder of ascent on which the soul is physically strengthened and increased so that it will be capable of seeing and touching the beautiful. Like Whitman later, the English Platonists emphasize the physicality of the soul approaching the highest vision of beauty on the ladder of ascent. In Thomas Taylor's influential 1804 revision of the Sydenham edition of the Symposium, for instance, the description of the soul fully fortified at the end of this ascent is translated as follows: "till thus being strengthened and increased, he perceives what that one science is which is so singularly great." 19 In his 1818 translation of the Symposium, Percy Shelley, who knew well the Sydenham and Taylor editions, translates the passage as follows: "until, strengthened and confirmed, he should at length steadily contemplate one science" (56). The actual Greek word surprisingly provides an even surer ground for comparison since, in Greek, this strengthening is rhōstheis, as close as one can get to "robust" in English. In Whitman, moreover, the word "robust" appears in the final version of the poem (1881), not in the original 1855 edition where we simply have: "Now I stand on this spot with my soul" ( $L G 1855,50)$. Whitman's later emphasis upon the strengthening of the much labored soul ("Now on this spot I stand with my robust soul") indicates a striking affinity with the stages of ascent in Emerson and the mystical tradition he intensively studied and transformed for an American audience. ${ }^{20}$

Both Emerson and Whitman therefore depict the expanding self by radically transforming the traditional ladder of ascent into an ontological and poetic structure of power, and they locate this power in the site of textuality. In "Goethe" (1850), Emerson depicts representative personality not simply as past materials that need to be assimilated by a current self; rather, the reading process evokes a relationship between perceiver and poet, which imbues the textual frame with a vital form of energy that it does not ordinarily possess. Emerson's repeated desire to inhabit all points of view becomes, in this instance, a reader's desire for another beyond the immediate parameters of the individual body. Peering into the face of the "right book," the reader seeks to "meet the eyes of the most determined of men" whose "force and terror inundate every word": 
It makes a great difference to the force of any sentence, whether there be a man behind it, or no. In the learned journal, in the influential newspaper, I discern no form, only some irresponsible shadow, oftener, some monied corporation, or some dangler, who hopes in the mask and robes of his paragraph, to pass for somebody. But, through every clause and part of speech of a right book, I meet the eyes of the most determined of men: his force and terror inundate every word: the commas and dashes are alive; so that the writing is athletic and nimble, can go far and live long. (CW, 4:162)

Here, the mimetic dilemma that inevitably haunts the textual process has been overcome. Instead of having to see through an "irresponsible shadow" or, in Whitman's words, the "eyes of the dead," the reader finds that the text may yield an empowered textual intimacy: two eyes meeting each other through the textual medium and enlivening the reading experience so that even the "commas and dashes are alive." Whitman's self-described effort "to put a whole living man in the expression of a poem, without wincing" is certainly a grand figuration of Emerson's insistence above that the "right book" can evoke a form of empowered intimacy. ${ }^{21}$ But Whitman's extraordinary capacity to imagine how the poetic process unfolds in space and time, with the physical bodies of poet and reader both interdependent and separate, also suggests a greater anxiety in regard to seeing through the eyes of another.

As Ed Folsom and Kenneth M. Price have argued, Whitman "turns the impersonal act of reading into an intimate experience and talks to us as if the print on the page were itself a sentient being, aware of our presence." 22 Whereas, as in the 1855 preface, this relationship between reader and poet may express a form of intimate union in which a new self is formed from out of all the old divisions, Whitman also imagines the consequences of such metempsychotic assimilation. Thus, in Section 28 of "Song of Myself," Whitman does what Emerson never attempted to do-to make his audience see through the eyes not of the authorial self, but of the dispossessed:

Is this then a touch? quivering me to a new identity,

Flames and ether making a rush for my veins,

Treacherous tip of me reaching and crowding to help them,

My flesh and blood playing out lightning to strike what is hardly different from myself, On all sides prurient provokers stiffening my limbs,

Straining the udder of my heart for its withheld drip,

Behaving licentious toward me, taking no denial,

Depriving me of my best as for a purpose,

Unbuttoning my clothes, holding me by the bare waist,

Deluding my confusion with calm of the sunlight and pasture-fields,

Immodestly sliding the fellow-senses away,

They bribed to swap off with touch and go and graze at the edges of me, 
No consideration, no regard for my draining strength or my anger,

Fetching the rest of the herd around to enjoy them a while,

Then all uniting to stand on a headland and worry me.

The sentries desert every other part of me,

They have left me helpless to a red marauder,

They all come to the headland to witness and assist against me. $(L G, 57)$

This stanza plays out the principal conflict of "Song of Myself": both the desire for self-transcendence and the fear that such an expansion may, in fact, be a form of rape. While Emerson always conceived of the assimilating self as an ideal fantasy that could never really come to be, Whitman transgresses these ideal bounds to portray the point of view of the self violently subsumed by the will of an authorial self. By charging the scene with a sexual, violent energy, moreover, he re-imagines the "touch" or "firm sure grasp" of the 1855 preface as an act of plunder, since the "touch" that brings with it a "new identity" is "licentious" and "immodest," possessing "no consideration" for the passive, emasculated, ever-weakening subject being subsumed by the greater whole.

Even as Whitman indicates such violent assimilation to be a social reality, he characterizes the red marauder's advances and the weakening resistance against them as a war raging inside the individual himself. The speaker comes to experience firsthand the fuller panoply of metempsychotic assimilation in the sense that he must endure both sides of its dialectic, not simply the feature of consciousness which reaches out to assume and take in, but the other aspect that reluctantly gives way as a new, empowered and robust entity emerges. Consequently, the speaker is a being divided, not just from the herd that crowds round him, but from himself, for, in this instance, he has no access to the active part of himself. On the contrary, he waits helplessly as all his internal vitality is drained from him: "Straining the udder of my heart for its withheld drip." Because of Whitman's visceral depiction of embodiment, the new life in running its course-in becoming a recipient of America's teeming wealth and eventually offering itself as the material for yet another heir-will have to experience a bloody division, much more violent and terrifying than Emerson's articulations of metempsychotic and metamorphic transformation.

While both writers share the bolder strokes of an ascending, metempsychotic sequence collapsed into the mind and body of the new American individual, Whitman's depiction of the loss of individual existence fused with a notion of individual sacrifice reaches biblical intensity. As Section 28 reveals, the speaker's internal struggle echoes some of the events leading up to the death and resurrection of Jesus Christ; the speaker's "flesh and blood" become the sacrifice that the 
herd demands, a herd that first strips him of his vestments and then bribes each other for pieces of him, strikingly reminiscent of Christ's passion on the cross where he is stripped naked by the Romans who proceed to gamble for his robes. Whitman even evokes the sense of Roman imperial power being part of the crime, for the mob transforms into "sentries" who come "to witness and assist" against the speaker. These intertextual, biblical allusions intensify and heighten the drama of this sequence, yet they do not define it; they reverberate as a past formulation of a present and, therefore, more pressing American predicament. Since the conflict explicitly functions as an internal one, the speaker cannot represent a Messiah or indicate an undiluted Christian sensibility. Instead, the speaker encompasses both sides of the conflict: he is both a sacrifice of "flesh and blood" and the "greatest traitor," Jesus and Judas made momentarily one and bound up in a pattern that echoes the older drama but cannot be reduced to it: "I am given up by traitors, / I talk wildly, I have lost my wits, I and nobody else am the greatest traitor, / I went myself first to the headland, my own hands carried me there. // You villain touch! what are you doing? my breath is tight in its throat, / Unclench your floodgates, you are too much for me" $(L G, 58)$. Since it is the speaker who undergoes the metamorphosis, the "touch" that "quiver[s]" him "to a new identity" is now unequivocally his own. $\mathrm{He}$ and "nobody else" is the "greatest traitor" for his "own hands carried [him] there," as he finds himself already being shaped anew, with "his breath . . . tight" in another's throat. The speaker does not accept the process without resistance; he recognizes it as something alien, as something to which he must submit although he has no power over it.

In Whitman Possessed, Mark Maslan emphasizes not simply the act, but the structure of penetration in the violent encounter above, interpreting it in terms of the larger soul/body relationship in "Song of Myself": "Whitman personifies what might ordinarily be considered part of himself - his soul - as an independent agent that takes violent, if amorous, possession of his body." 23 For Maslan, such a structure of penetration and the accompanying subversion of individual identity do not "undermine structures of cultural or political authority," as critics have argued. "On the contrary, by portraying sexual desire as an invasive, automating force, [Whitman] identifies it with the oldest form of cultural authority in the Western tradition: inspiration" (142-143). Indeed, in Section 28 of "Song of Myself," because it is forced to accept another's consciousness, the penetrated self ironically becomes the conduit of great power. Just four sections earlier, Whitman has already prepared his readers to understand such penetration in the grandest terms at his disposal: "Unscrew the locks from the doors! / Unscrew the doors themselves from their jambs!" Here, "the pass-word prime- 
val," the "sign of democracy" opens the sublime doorway or threshold of the body to receive the universe. "Through me the afflatus surging and surging, through me the current and index," Whitman intones, announcing himself as the threshold through which all must pass $(L G, 52)$.

Consequently, the crisis of the fluid and swallowing self in Section 28 can be understood as a grand fulfillment not simply of the Romantic conception of expansive individuality, but of the ancient cosmologies of ascent and reincarnation that made such a concept possible in the first place. Whitman's own Romantic assumptions and his lifelong support of the political doctrine of Manifest Destiny certainly underwrite his filial devotion to an expansive and assimilating notion of American individuality. ${ }^{24}$ It is no longer a matter of the feudal privilege of kings, but a divine power now up for grabs from below, assumed by the individual who acquires vast material holdings, essentially a Romantic philosophy for the self-made man. Because Whitman simultaneously "eradicates the distinction between the reflections within the mind and things in the world," a distinction that is vital for Emerson, Whitman's realization of the ascending metempsychotic self will inevitably involve witnessing or even assisting in the graphic pillaging of another's body. No longer simply a cognitive pattern, this assimilation of other selves must viscerally entail the greater American record, not simply the overthrow of the tyrannical feudal order, but also the conquest of the Native peoples and the crimes of slavery, which both Emerson and Whitman keenly acknowledged.

In the often violent play of transcendentalism's assimilating self, we witness the predicament of an American Faust who desires to taste every conceivable experience with no conventional moral censure, neither a Mephistopheles to tempt him nor an ideal Margaret to redeem him. But there are emergent moral compasses in Emerson and Whitman nonetheless. To the last, Emerson insisted upon an elusive immanence-in the words of "Experience," "in the solitude to which every man is always returning, he has a sanity and revelations, which in his passage into new worlds he will carry with him" (CW, 3:49). While championing the "passage into new worlds" as a focal point of his poetry, Whitman attends to another form of morality. In The Scapegoat (1982), René Girard argues that the scapegoat mechanism, which functions in all religion and myth, is challenged and potentially demystified when we no longer listen solely to the side of the persecutor, but see through the eyes of the innocent victim. ${ }^{25}$ In "Song of Myself" especially, Whitman attempts to show that the truly empowered self, even in its failures, seeks to encompass all perspectives. This self ascends the ladder of being with robust assimilation coming to mean more than simply an unquenchable, even impossible desire for expansion; it means learning 
the greater lesson of the historical series and inhabiting the perspectives of both persecutor and victim. This doubleness is a position that vigorously generates contrariety, but it also implicitly reflects a genuine desire to understand the other, for the blind mechanism that allows violent persecution is exposed to all eyes when one has to consider violence not "second or third hand," nor "through the eyes of the dead," but in relation to one's own spiritual and physical constitution.

\section{Ming Chuan University}

\section{NOTES}

1 Walt Whitman, Leaves of Grass, Comprehensive Reader's Edition, ed. Harold W. Blodgett and Sculley Bradley (New York: New York University Press, 1965). Hereafter, $L G$.

2 Martha Nussbaum, Upheavals of Thought: The Intelligence of the Emotions (Cambridge: Cambridge University Press, 2001), 656-661. For another reading of Whitman's counter-cosmology, see Michael Moon, Disseminating Whitman (Cambridge: Harvard University Press, 1991), 60-61.

3 Ralph Waldo Emerson, The Collected Works of Ralph Waldo Emerson, ed. Robert E. Spiller, Alfred R. Ferguson, Joseph Slater, Douglas Emory Wilson, Jean Ferguson Carr, Wallace E. Williams, Philip Nicoloff, Robert E. Burkholder, and Barbara L. Packer (Cambridge: Harvard University Press, 1971-2003), 2:8. Hereafter, $C W$. Also see Michael Corrigan, "The Metempsychotic Mind: Emerson and Consciousness," Fournal of the History of Ideas, 71 (July 2010), 433-455.

4 Ralph Waldo Emerson, The Early Lectures of Ralph Waldo Emerson, ed. Stephen E. Whicher and Robert E. Spiller (Cambridge: Harvard University Press, 1959-1972), $1: 32$.

5 Laura Dassow Walls, Emerson's Life in Science: The Culture of Truth (Ithaca: Cornell University Press, 2003), 187-193. Also see Louis Menand, The Metaphysical Club: A Story of Ideas in America (New York: Macmillan, 2002), 177-200; and David William Bates, Enlightenment Aberrations: Error and Revolution in France (Ithaca: Cornell University Press, 2002), 248-249.

6 See particularly the notion of peopling a new land through reversal or conversion; Stanley Cavell, This New Yet Unapproachable America (Albuquerque: Living Batch Press, 1989), 92-93.

7 See also Emerson's imagery of ascent in Representative Men (1850): the repeated endeavors of great individuals to ascend "the ladder that leads up to man and to God" $(C W, 4: 81)$.

8 Tenney Nathanson, Whitman's Presence (New York: New York University Press, 1992), 31.

9 Philip Fisher, Still the New World (Cambridge: Harvard University Press, 1999), 60.

10 Donald E. Pease, Visionary Compacts: American Renaissance Writings in Cultural Context (Madison: University of Wisconsin Press, 1987), 129. 
11 D. J. Moores, Mystical Discourse in Wordsworth and Whitman: A Transatlantic Bridge (Leuven, Belgium: Peeters Publishing, 2006), 69.

12 See Len Gougeon, "Emerson, Whitman, and Eros," Walt Whitman Quarterly Review 23 (Winter/Spring 2006), 126-146. Gougeon explores the nineteenth-century construction of a "sanitized and stilted view of Emerson" (127) and its problematic influence on literary criticism. Unlike many critics who distance Whitman and his sensuality from Emerson, Gougeon moves decisively to emphasize that Emerson not only approved of Whitman's notion of the body, but pursued a very similar conception of the body's relationship to the soul: "Emerson and Whitman sought to achieve a dynamic balance between body and soul that enhanced both entities tremendously. As a result, they were able to offer a vision of unity and spontaneous spiritual and physical life to an ailing and fragmented society" (143). Whereas many critics attempt to separate Whitman's notion of the self from an ostensibly ascetic and spiritual Emerson, we can see, in this context, that Whitman's adaptation of Emerson's metempsychotic self underscores precisely this process of achieving balance between body and soul and bringing both aspects into synthesis.

13 Harold Bloom, ed., Bloom's Modern Critical Views: Walt Whitman, Updated Edition (New York: Chelsea House, 2006), 238.

14 Harold Bloom, How to Read and Why (New York: Simon and Schuster, 2001), 92.

15 Walt Whitman, Leaves of Grass (1855), xi. Hereafter, LG 1855. Available on the Walt Whitman Archive (www.whitmanarchive.org).

16 The Symposium of Plato, trans. Percy Bysshe Shelley (South Bend, Indiana: St. Augustine's Press, 2002), 53, 56.

17 Ralph Waldo Emerson, The fournals and Miscellaneous Notebooks of Ralph Waldo Emerson, ed. William H. Gilman and Ralph H. Orth et al. (Cambridge: Harvard University Press, 1960-1982), 8:251; emphasis added.

18 Floyer Sydenham. The Banquet, A Dialgue of Plato Concerning Love, The Second Part (London: W. Sandby, 1767), 223.

19 See Plato: The Symposium, trans. Thomas Taylor and Floyer Sydenham (Somerset: Prometheus Trust, 2002), 61.

20 See Robert D. Richardson Jr., Emerson: The Mind on Fire (Berkeley: University of California Press, 1995), 346-348.

21 Joel Myerson, ed., Whitman in His Own Time (Iowa City: University of Iowa Press, 2002), 17.

22 Ed Folsom and Kenneth M. Price, Re-Scripting Walt Whitman: An Introduction to His Life and Work (Malden: Blackwell, 2005), 46.

23 Mark Maslan, Whitman Possessed: Poetry, Sexuality, and Popular Authority (Baltimore: Johns Hopkins University Press, 2001), 54.

24 Betsy Erkkila, Whitman the Political Poet (Oxford: Oxford University Press, 1989), 39.

25 René Girard, The Scapegoat, trans. Yvonne Freccero (Baltimore: Johns Hopkins University Press, 1986), 198-212. 